\author{
Katarzyna CZerwińsKa-Koral ${ }^{1}$
}

\title{
Pojęcia niedookreślone w przepisach ustawy o kształtowaniu ustroju rolnego
}

\section{Zagadnienia wstępne}

Dnia 30 kwietnia 2016 r. weszły w życie przepisy ustawy z dnia 14 kwietnia 2016 roku o wstrzymaniu sprzedaży nieruchomości Zasobu Własności Rolnej Skarbu Państwa ${ }^{2}$ (zwaną dalej: w.s.n. ZWRSP). Zgodnie z art. 7 w.s.n. ZWRSP wprowadzono szereg zmian do ustawy z dnia 11 kwietnia 2003 r. o kształtowaniu ustroju rolnego, ${ }^{3}$ co spowodowało modyfikację w szczególnych zasadach obrotu rolnego. Istotne wydaje się dodanie do u.k.u.r preambuły, z której wynika, że ustawa uchwalana jest w „celu wzmocnienia ochrony i rozwoju gospodarstw rodzinnych, które w myśl Konstytucji Rzeczypospolitej Polskiej stanowią podstawę ustroju rolnego Rzeczypospolitej Polskiej, dla zapewnienia właściwego zagospodarowania ziemi rolnej w Rzeczypospolitej Polskiej, w trosce o zapewnienie bezpieczeństwa żywnościowego obywateli i dla wspierania zrównoważonego rolnictwa prowadzonego w zgodzie z wymogami ochrony środowiska i sprzyjającego rozwojowi obszarów wiejskich (...)." Jako że preambułę należy traktować jako integralną część prawa, mającą znaczenie prawne w procesie interpretacji treści aktu normatywnego, musi być ona uwzględniania przy procesie interpretacji przepisów ustawy i przy jej stosowaniu. Preambuła wyjaśnia ratio legis ustawy, wskazuje na wartości, które powinny być uwzględniane przy wykładni poszczególnych przepisów o charakterze normatywnym. Ustawodawca odwołuje się w niej do Konstytucji RP, która stwierdza, że gospodarstwa rodzinne stanowią podstawę ustroju rolnego Rzeczpospolitej Polskiej oraz że zmiany przepisów mają na celu wzmocnienie ochrony i rozwoju gospodarstw rodzinnych, zapewnienie właściwego zagospodarowania ziemi rolnej, troskę o zapewnienie bezpieczeństwa żywnościowego obywateli oraz wspieranie

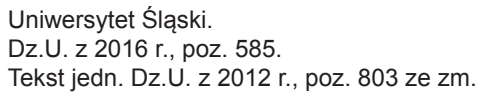


zrównoważonego rolnictwa prowadzonego w zgodzie z wymogami ochrony środowiska i sprzyjającego rozwojowi obszarów wiejskich. ${ }^{4}$

Po wprowadzeniu zmian w u.k.u.r przepisami w.s.n. ZWRSP w literaturze pojawiły się wyraźne głosy krytyki, wskazujące na naruszenie prawa własności ${ }^{5}$ przez niektóre ograniczenia prawa własności.

Jak wydaje się, granica pomiędzy stwierdzeniem, że przepisy u.k.u.r. urzeczywistniają prawo własności (rolniczej) i zarazem stanowią jej (gospodarstwa rodzinnego) ochronę a stwierdzeniem, że stanowią one ograniczenie prawa własności, wydaje się bardzo płynna. Aby twierdzić, że przepisy u.k.u.r. kształtują prawo własności rolnej, należy zapewnić realną ochronę gospodarstwa rodzinnego. Tymczasem podstawowy zarzut, jaki można podnieść przeciwko przepisom wprowadzającym ograniczenia własności w u.k.u.r. jest taki, że są one niesprecyzowane, zawierają wiele wyrażeń nieostrych i niedookreślonych.

\section{Zwroty niedookreślone - analiza szczegółowa}

Jest rzeczą oczywistą, że w każdym akcie prawnym możemy wyróżnić przepisy o charakterze podstawowym, które odgrywają zasadniczą rolę, ale także przepisy nieostre mające na celu zapewnienie elastyczności aktu prawnego. ${ }^{6}$ Ustawodawca tworzy świadomie pewne konstrukcje prawne, jak zwroty niedookreślone, zwroty szacunkowe oraz klauzule generalne. ${ }^{7}$ u.k.u.r.

Przyjrzyjmy się niektórym konstrukcjom prawnym zawartym w przepisach

Po pierwsze, w przypadku zmiany wspólnika lub przystąpienia nowego wspólnika do spółki osobowej w rozumieniu ustawy Kodeks spółek handlowych, która jest właścicielem nieruchomości rolnej, Agencja działająca na rzecz Skarbu Państwa „może” złożyć oświadczenie o nabyciu tej nieruchomości za zapłatą równowartości pieniężnej odpowiadającej jej wartości rynkowej (art. 3b). Jest to przykład tzw. uznania administracyjnego. ${ }^{8}$ Istotą uznania administracyjnego jest uprawnienie or-

M. Korzycka, Analiza prawna przepisów ustawy o wstrzymaniu sprzedaży nieruchomości Zasobu Własności Rolnej Skarbu Państwa oraz o zmianie niektórych ustaw zwana dalej ustawą (druk senacki nr 124), www. senat.gov. $\mathrm{pl} /$ prace/opinie-i-eksperzyzy, s. 3.

5 Zob. np. J. Pisuliński, O niektórych osobliwościach obrotu nieruchomościami rolnymi, „Rejent” 2016, nr 5, s. 23 i n., K. Maj, Zmiany w ustawie o kształtowaniu ustroju rolnego obowiązujące od dnia 30 kwietnia 2016 r., „Krakowski Przegląd Notarialny" 2016, nr 2, s. 49 i n., Z. Truszkiewicz, Nieruchomość rolna i gospodarstwo rolne w rozumieniu U.K.U.R., „Krakowski Przegląd Notarialny” 2016, nr 2, s. 139.

$6 \quad$ K. Bochania, Znaczenie klauzul generalnych w stosowaniu prawa krajowego i międzynarodowego, [w:] Klauzule generalne w prawie krajowym i obcym, L. Zacharko (red.), Katowice 2016, s. 19.

7 M. Śliwka, Znaczenie zwrotów niedookreślonych na tle orzecznictwa polskiego Trybunału Konstytucyjnego, „Studia luridica Lublinesia" 2010, nr 1, s. 261; niedookreśloność jako właściwość zwrotu odnosi się do znaczenia zwrotu, zaś nieostrość dotyczy jego zakresu. Niedookreśloność jest właściwością języka, nieostrość ma charakter logiczny.

8 Chodzi o szerokie rozumienie uznania administracyjnego, ponieważ w omawianym przykładzie nie mamy do czynienia z decyzją administracyjną (art. 107 k.p.a.). Chodzi zatem o decyzję w szerokim rozumieniu, tj. czynność czyli akt woli, który dotyczy posiadanej wiedzy z przepisów ustawy (akt wiedzy). 
ganu administracji (w tym wypadku Prezesa ANR) do kształtowania w konkretnej sprawie skutków prawnych w granicach swobody, które pozostawiają organowi przepisy prawa. ${ }^{9}$ Upoważnienie do uznania może zostać przez ustawodawcę wyrażone w różny sposób, ale najczęściej stosowaną metodą jest użycie słowa „może”. Oznacza to, że organ „może, ale nie jest zobowiązany” wydać rozstrzygnięcie o określonej treści lub w określony sposób się zachować. Przy zaistnieniu opisanego w hipotezie normy stanu faktycznego organ administracji dokonuje zatem wyboru jednego z dopuszczalnych skutków prawnych.

Drugi przykład uznania administracyjnego jest zawarty w art. 3 ust. 4, art. 3a i art. 3b. W sytuacji prawa pierwokupu ANR przy sprzedaży nieruchomości rolnej (art. 3 ust. 4), prawa pierwokupu udziałów i akcji w spółce prawa handlowego, która jest właścicielem nieruchomości rolnej (art. 3a), ustawodawca nie sformułował żadnych przesłanek, po których spełnieniu ANR korzysta lub nie skorzysta z prawa pierwokupu i prawa nabycia. Ustawodawca posługuje się zwrotem ,przysługuje prawo pierwokupu", co oznacza, że Agencja działająca na rzecz Skarbu Państwa „może” (a nie jest zobligowana) skorzystać z tego uprawnienia przewidzianego przepisami ustawy. Zauważalny jest brak w tym zakresie jakichkolwiek kryteriów, brak określenia precyzyjnych przesłanek (warunków), po których zaistnieniu Agencja będzie korzystać ze swoich uprawnień.

Podobnie nie sformułowano przesłanek w art. 3b u.k.u.r., tj. w przypadku złożenia przez ANR oświadczenia o nabyciu nieruchomości rolnej za zapłatą równowartości pieniężnej odpowiadającej jej wartości rynkowej. Taki zabieg ustawodawcy należy ocenić negatywnie, bowiem od zaistnienia określonych przesłanek powinno zależeć wykonanie lub niewykonanie uprawnień przez Agencję. Agencja nie może sobie pozwolić na uznaniowość. Brak szczegółowych i konkretnych przesłanek może w praktyce powodować zbyt daleką dowolność przy podejmowaniu decyzji.

Wskazane sytuacje można uznać za przykłady szerokiego ujęcia uznania administracyjnego. Podstawy swobodnego uznania mogą być trojakiego rodzaju: pierwsza to bezpośrednie, wyraźne udzielenie władzy administracyjnej upoważnienia do swobodnego decydowania. Kolejną podstawę stanowi pośrednie upoważnienie przez ustawę do decydowania według swobodnego uznania (ma to miejsce w przypadkach, gdy ustawa mówi, że organ administracyjny ,może”, a także gdy ustawa wymienia pewną czynność organu administracji bez jej materialnego ograniczenia, np. ,przenosi”, ,zezwala”, „,korzysta”).

Ostatnią podstawą swobodnego uznania w administracji, akceptowaną przez zwolenników szerokiego ujęcia uznania, jest użycie w ustawie zwrotów niedookreślonych. Takie ujęcie uznania administracyjnego to zbiorcza kategoria obejmująca 
wszelkie sposoby przyznania przez przepisy organowi stosującemu prawo elastyczności, tj. pozostawienie mu w pewnym zakresie luzu decyzyjnego. ${ }^{10}$

Swobodne uznanie władz administracyjnych jest jedną z najbardziej typowych cech administracji publicznej i jednocześnie wyjątkiem od zasady związania z prawem, pojmowanej jako konieczność zastosowania przewidzianego w danej normie prawnej następstwa prawnego w sytuacji, gdy w konkretnym stanie faktycznym spełniona zostanie dyspozycja tej normy. ${ }^{11}$

Przykład takiego rodzaju uznania znajdziemy również w u.k.u.r. Zgodnie z treścią art. 2a ust. 4 u.k.u.r. nabycie nieruchomości rolnej przez podmioty opisane w tym przepisie może nastąpić „,za zgodą Prezesa Agencji wyrażoną w drodze decyzji administracyjnej" wydawanej na wniosek zbywcy (art. 2a ust. 4 pkt 1) lub osoby fizycznej zamierzającej utworzyć gospodarstwo rodzinne (art. 2a ust. 4 pkt 2). I dalej, zgodnie z art. 2a ust. 3 u.k.u.r. wniosek o zezwolenie na nabycie nieruchomości rolnej przez inny podmiot niż rolnik indywidualny może złożyć zbywca, przy czym musi wykazać zaistnienie określonych okoliczności. Po pierwsze, musi wykazać, że nie było możliwości nabycia nieruchomości rolnej przez podmioty, o jakich mowa w art. 2a ust. 4 musi zatem przedłożyć Prezesowi ANR dowody na brak możliwości nabycia nieruchomości rolnej przez wszystkie podmioty opisane w art. 2a ust. 3 pkt 1. Przepis ten jest bardzo szeroko sformułowany. Wynika z niego bowiem, że zwrócono się do wszystkich osób bliskich zbywcy, wszystkich jednostek samorządu terytorialnego (chodzi o gminy, powiaty, województwa i ich związki ${ }^{12}$ ), Skarbu Państwa lub działającej na jego rzecz Agencji oraz wszystkich osób prawnych działających na podstawie przepisów o stosunku Państwa do Kościoła katolickiego w Rzeczpospolitej Polskiej, o stosunku Państwa do innych kościołów i związków wyznaniowych oraz o gwarancjach wolności sumienia i wyznania. Niektórzy wskazują, iż tak sformułowany przepis powoduje, że jest to niewykonalny warunek. ${ }^{13}$

Jak wskazuje A. Ostrowska, (Teoretyczne aspekty uznania administracyjnego, [w:] Wykładnia prawa. Odrębności w wybranych gałęziach prawa, Lublin 2006, s. 23-25), na tle różnych stanowisk doktryny wyodrębnić należy dwa zasadnicze ujęcia konstrukcji uznania: ujęcie wąskie, którego zwolennicy dostrzegają realizacje dopiero na etapie określania następstw prawnych konkretnego, ustalonego już stanu faktycznego oraz ujęcie szersze, zgodnie z którym uznanie administracyjne wiąże się również z interpretacją pojęć nieostrych na poziomie ustalania stanu faktycznego. Zwolennicy szeroko rozumianego uznania administracyjnego przyjmują, że z użyciem władzy dyskrecjonalnej przez organ mamy do czynienia na etapie interpretacji normy prawnej, a następie na etapie subsumcji, w wypadku gdy ustawodawca w danej nomie użył pojęć nieostrych. W tym bowiem wypadku organ ustala znaczenie użytych przez ustawodawcę w normie prawnej wyrażeń, zarówno w oparciu o ich literalne brzmienie, ustalone w drodze wykładni (językowej, językowo-logicznej, systemowej, celowościowej) i zasady logiki, jak też poprzez odwoływanie się do celu prawodawcy, funkcji normy, ogólnych zasad prawa zasad słuszności. Za przejaw działania uznaniowego można tutaj również przyjąć dokonywanie różnego rodzaju ocen przez organ wydający decyzję, często porównawczych, pozwalających ustalić stopień, skalę lub natężenie wystawienia określonych faktów.

11 A. Ostrowska, Teoretyczne aspekty uznania administracyjnego, op. cit., s. 21.

12 K. Maj, Zmiany w ustawie o kształtowaniu ustroju rolnego, op. cit., s. 82.

13 Ibidem, s. 82-83. 
Po drugie, zbywca musi wykazać, że nabywca daje rękojmię należytego prowadzenia działalności rolniczej. Również w przypadku złożenia wniosku przez osobę fizyczną zamierzającą utworzyć gospodarstwo rodzinne pojawia się przesłanka „dawania rękojmi należytego prowadzenia działalności rolniczej.” Jest to przesłanka, od której spełnienia/niespełnienia zależy wydanie pozytywnej bądź negatywnej decyzji, czyli wyrażenia bądź niewyrażenia zgody przez Prezesa ANR na nabycie (zbycie) nieruchomości rolnej. Innymi słowy, od tej decyzji zależy możliwość wykonania jednego z uprawnień właścicielskich, tj. rozporządzenia rzeczą (art. 140 k.c.). „Dawanie rękojmi należytego prowadzenia działalności rolniczej” stanowi kryterium wiążące osobę nabywcy, a jednocześnie jest to pojęcie, które nie zostało zdefiniowane przez ustawodawcę na gruncie omawianej ustawy. Będzie zatem podlegało ocenie organu stosującego prawo. ${ }^{14}$ Należałoby posiłkować się znanym Kodeksowi cywilnemu pojęciem należytej staranności.

W oparciu o tak niejednoznaczne przepisy Prezes ANR musi dokonać stosowania prawa. Stosowanie prawa to działalność władcza organów państwa polegająca na wydawaniu decyzji indywidualno-konkretnych (akty stosowania prawa) na podstawie norm prawnych (aktów tworzenia prawa). ${ }^{15}$ Zatem akt stosowania prawa to proces konkretyzacji norm prawnych w indywidualnej i konkretnej sprawie. Konkretyzacja norm materialnego prawa administracyjnego polega na rozstrzyganiu indywidualnych spraw administracyjnych w drodze decyzji administracyjnych. Decyzje te, tak jak w omawianym przypadku, wydaje organ administracji publicznej, czyli podmiot usytuowany w ramach władzy wykonawczej, a nie sądowniczej. Należy też pamiętać, że Prezes ANR działa nie tylko zgodnie z prawem (zasada legalności), ale i także celowo (zasada celowości), ponieważ jako podmiot administracji publicznej realizuje określony interes publiczny (społeczny). Administracyjne stosowanie prawa nie jest więc mechaniczną czynnością konkretyzacji norm ogólnych na jednostkowe, ale jest też sposobem realizowania pewnych celów publicznych. ${ }^{16}$

Zauważyć należy, że przepisy prawne, które dotyczą własności rolniczej (gospodarstwa rolnego) często zawierają tego typu normy. Przykładowo w art. 213 k.c. czytamy ,jeżeli zniesienie współwłasności gospodarstwa rolnego przez podział między współwłaścicieli byłoby sprzeczne z zasadami prawidłowej gospodarki rolnej, sąd przyzna to gospodarstwo temu współwłaścicielowi, na którego wyrażą zgodę wszyscy współwłaściciele." Zgodnie z art. 214 § 1 k.c. w razie braku zgody wszystkich współwłaścicieli, sąd przyzna gospodarstwo rolne temu z nich, który je prowa-

14 M. Korzycka, Analiza prawna przepisów ustawy, op. cit., s. 6.

15 L. Morawski, Wstęp do prawoznawstwa, Toruń 1996, s. 121; proces stosowania prawa składa się z kilku etapów: 1) wyjaśnienie i ustalenie stanu faktycznego, 2) wykładnia i ustalenie stanu ustawowego (hipotezy normy prawnej), 3) subsumcja, czyli udzielenie odpowiedzi na pytanie, czy stan faktyczny odpowiada stanowi przewidzianemu przez ustawę, 4) ustalenie skutku prawnego udowodnionego faktu.

16 D. Gregorczyk, Stosowanie prawa administracyjnego przez sąd administracyjny, [w:] Sądowe stosowanie prawa, B. Dolnicki (red.), Katowice 2014, s. 53. 
dzi lub stale w nim pracuje, chyba że interes społeczno-gospodarczy przemawia za wyborem innego współwłaściciela. Z kolei w $\$ 2$ zapisano: ,Jeżeli warunki przewidziane w paragrafie poprzedzającym spełnia kilku współwłaścicieli albo jeżeli nie spełnia ich żaden ze współwłaścicieli, sąd przyzna gospodarstwo rolne temu z nich, który daje najlepszą gwarancję jego należytego prowadzenia."

Przesłanka „dawania rękojmi należytego prowadzenia działalności rolniczej” odpowiada w swojej treści przesłance ,dawania najlepszej gwarancji należytego prowadzenia gospodarstwa rolnego", zatem być może w oparciu o orzecznictwo i poglądy doktryny dotyczące art. 214 § 2 k.p.c. będzie można ustalić jej zakres. Zauważalny jest brak przesłanek, w oparciu o które Prezes ANR będzie decydował, że dana osoba będzie należycie prowadziła działalność rolniczą. Jak zauważył SN w postanowieniu z dnia 17 października 2000 r. (I CKN 832/98), ${ }^{17}$ kryterium najlepszej gwarancji należytego prowadzenia gospodarstwa rolnego" odwołuje się do kwalifikacji podmiotowych współwłaścicieli i to sąd (zatem organ stosujący prawo) powinien dokonać w tym zakresie oceny posiadania odpowiednich kwalifikacji współwłaścicieli. Jak się wydaje, organ wydający decyzje w przedmiocie zgody na nabycie nieruchomości rolnej winien posługiwać się wypracowaną przez lata obowiązywania art. 214 k.c. wykładnią tej przesłanki. Z drugiej jednak strony pamiętać należy, że ,język norm prawnych posługuje się językiem etnicznym, którego reguły znaczeniowe - szeroko rozumiane - kształtowane są w swobodnej i zmieniającej się praktyce używania języka", na co zwrócił uwagę SN w uchwale z dnia 21 listopada 2001 r. (I KZP 26/2001). ${ }^{18}$ Zatem wykładnia SN będzie miała zastosowanie do przepisów Kodeksu cywilnego zmieniających treść art. 213 i art. 214.

Podobnie WSA w Gliwicach w wyroku z dnia 9 listopada 2010 r. (IV SA/GI 276/10) ${ }^{19}$ zwrócił uwagę na takie cechy języka prawnego, jak zależność od zmieniających się kontekstów pozajęzykowych, takich jak stosunki społeczne, ekonomiczne czy polityczne.

Ponadto zgodnie z art. 2a ust. 4 pkt c u.k.u.r. zbywca musi również wykazać, że w wyniku nabycia nie dojdzie do nadmiernej koncentracji gruntów rolnych. Zwrot „nadmierna koncentracja gruntów rolnych" to kolejne pojęcie niezdefiniowane przez ustawodawcę. Samo pojęcie „koncentracja gruntów rolnych” jest nieostre, a dodatkowo zawęża zwrot szacunkowy „nadmierna”. W przypadku predykatu „,nadmierna" mamy do czynienia z nieostrością oczywistą i transparentną, gdzie zakres nieostrości desygnatów, o których można by te predykaty orzec, może być wyznaczony poprzez wskazanie pewnego punktu granicznego ${ }^{20}$ (liczba ha powyżej których moż-

OSNC 2003, nr 7-8, poz. 105

Opublikowane na stronie internetowej SN.

Orzeczenia.nsa.gov.pl.

A. Marmor, Varietes of Vadueness In the Law, „USC Legal Studies Research Paper Series” 2013, nr 12-8. 
na uznać, że ich liczba jest nadmierna). W połączeniu zaś obu nieostrych pojęć pojawia nam się wielokierunkowa nieostrość. ${ }^{21}$

Jak widać okoliczności, które należy wykazać dla uzyskania zgody na nabycie nieruchomości rolnej przez podmioty nie będące rolnikami indywidualnymi, są nieostre. Pojęcia te samodzielnie będzie interpretował Prezes ANR, przy braku jakichkolwiek przesłanek do ich interpretacji.

Ustawodawca tworzy świadomie konstrukcje prawne typu „dawanie rękojmi należytego prowadzenia działalności rolniczej”, „nadmierna koncentracja gruntów rolnych", które poszerzają luz decyzyjny organów stosujących prawo, elastyczność prawa jest głównym celem wprowadzania do tekstu prawnego zwrotów niedookreślonych. ${ }^{22}$ Zwroty te jednak przesuwają obowiązek konkretyzacji normy na etap stosowania prawa i w związku z tym dają organom administracji pewną swobodę decyzyjną. ${ }^{23} \mathrm{Z}$ drugiej strony konstrukcje te rodzą pewne niebezpieczeństwa. ${ }^{24}$ Podkreśla to Trybunał Konstytucyjny wskazując, że nieodpowiednie użycie wynikającego z nich luzu decyzyjnego niesie ze sobą możliwość pojawienia się wątpliwości interpretacyjnych. Ponadto fakt, że konkretyzacja normy następuje nie w procesie tworzenia, a stosowania prawa, napotyka pewne trudności związane z ryzykiem arbitralności rozstrzygnięć organu stosującego prawo. ${ }^{25}$

Nieostrość zwrotów tekstu prawnego jest niepożądana zwłaszcza w przypadku stanowienia nakazów i zakazów adresowanych do obywateli. W takiej sytuacji może stanowić podstawę do zakwestionowania danej regulacji w związku z niedopełnieniem wymogu dostatecznej określoności norm dotyczących praw i wolności obywatelskich. ${ }^{26} \mathrm{~W}$ orzeczeniu z dnia 12 września 2005 r. ${ }^{27}$ Trybunał Konstytucyjny wskazuje na dwojakiego rodzaju niebezpieczeństwo, jakie wiąże się ze stosowaniem zwrotów niedookreślonych: ,,praktyka stosowania tych przepisów stosunkowo łatwo może ulec wypaczeniu, na skutek powoływania się na takie zwrot, bez próby wypełnienia ich treścią wynikającą z okoliczności danej sprawy i bez rzetelnego uzasadnienia komunikowanego adresatom rozstrzygnięcia."

Tam, gdzie ustawodawca pozostawia pewien zakres swobody rozstrzygania podmiotom stosującym prawo, a zatem m.in. tam gdzie organy administracji pu-

T. Gilbert-Studnicki, Wieloznaczność leksykalna w interpretacji prawniczej, Kraków 1978, s. 58 i n; S. Piekarczyk, Wielokierunkowa nieostrość w sądowym stosowaniu prawa Intencja prawodawcy a dyskrecjonalność sędziowska - antynomia czy kongruencja?, [w:] Klauzule generalne w prawie krajowym i obcym, L. Zacharko (red.), Katowice 2016, s. 169 i n.

M. Śliwka, Znaczenie zwrotów niedookreślonych na tle orzecznictwa polskiego Trybunału Konstytucyjnego, „Studia luridica Lublinesia" 2010, nr 1, s. 271.

Ibidem, s. 266-267.

Ibidem, s. 268.

Orzeczenie z 12 września 2005 r., SK 13/05. 
blicznej ujawnione są do działania w ramach przyznanej im władzy dyskrecjonalnej, pojawia się duże ryzyko wystąpienia różnego rodzaju nieprawidłowości.

W literaturze rozróżnia się: a) przekroczenie uznania, które zachodzi wówczas, gdy organ administracji wybiera następstwo prawne leżące poza ramami normy uznaniowej, b) niedobór uznania, który ma miejsce w sytuacji, gdy podmiot stosujący normę uznaniową nie czyni dostatecznego użytku z przyznanej mu władzy dyskrecjonalnej poprzez nieświadomość lub niedbałość, c) błędne zastosowanie uznania, z którym mamy do czynienia wówczas, gdy organ administracji nie kieruje się wyłącznie celem, który przyświecał ustawodawcy przy tworzeniu normy uznaniowej; źródło błędu tkwi w tym przypadku albo w niewłaściwej interpretacji intencji ustawodawcy albo w kierowaniu się przez organ względami personalnymi lub politycznymi, które nie są wprost przez prawo pożądane, d) błędne zastosowanie uznania polegające na naruszeniu podstawowych praw obywatelskich lub ogólnych zasad postępowania administracyjnego. ${ }^{28}$

Zatem stosowanie prawa w przypadku pojawienia się zwrotów niedookreślonych wymaga jasno określonych reguł. Reguły te w polskim systemie prawnym składają się na zasadę określoności prawa. ${ }^{29}$ Zasada ta należy do najważniejszych zasad w państwie prawa i jeden z esencjonalnych wymogów odnoszących się do rządów prawa w ujęciu formalnym. ${ }^{30}$ Celem tej zasady jest ustalenie bezwzględnie obowiązujących reguł postępowania w sferze ograniczania praw i wolności, a zatem jest wyjątkowo istotna przy ograniczaniu (ochronie) własności. Ustala ona zakres ingerencji państwa w sferę praw podmiotowych, w szczególności w prawo własności.

Zasada określoności jest standardem przyzwoitej legislacji, jest więc powinnością ustawodawcy. Oznacza to dla ustawodawcy obowiązek dążenia do prawa pewnego poprzez precyzyjne określenie swojej woli i precyzyjne wyrażenie jej w formie przepisu prawnego. Niejasne przepisy zmniejszają przewidywalność prawa, ponieważ stwarzają okazje do prawotwórczych interpretacji. ${ }^{31} \mathrm{~W}$ języku polskim słowo „określony” oznacza „sprecyzowany, wiadomy, pewny, jasny, wyraźny”. Uzasadnione jest zatem twierdzenie, że zasada określoności jest źródłem pewności prawa. ${ }^{32}$

Trybunał Konstytucyjny wypracował kilka definicji określoności. Ze względu na sposób rozumienia dzielą się one na dwie grupy. Do pierwszej należą te, które wyjaśniają zasadę określoności mając za podstawę głównie płaszczyznę aksjo-

\footnotetext{
28 A. Ostrowska, Teoretyczne aspekty uznania administracyjnego, op. cit., s. 26.

29 T. Pietrzykowski, Ujarzmienie Lewiatana - szkice o idei rządów prawa, Katowice 2014, s. 123 i n.

30 Ibidem, s. 119 i $\mathrm{n}$

31 I. Dziewulska-Gaj, O nieokreśloności konstytucyjnej zasady określoności, [w:] Sądowe stosowanie prawa, B. Dolnicki (red.), Katowice 2014, s. 75. 
logiczną. ${ }^{33} \mathrm{~W}$ tej grupie kładzie się nacisk na rolę zasady określoności i jej szczególną doniosłość w sferze praw i wolności. Trybunał Konstytucyjny skupił się tu na celu do osiągnięcia poprzez stosowanie zasady określoności - ograniczenie nadmiernej swobody organów stosujących prawo oraz przeciwdziałanie stworzeniu zbyt szerokich ram dla ich działalności, w których łatwo o arbitralne decyzje, a które nie mają umocowania w prawie, lecz we władzy i przeczą zasadzie państwa prawnego. ${ }^{34}$ „Ustawodawca nie może poprzez niejasne formułowanie tekstu przepisów pozostawić organom mającym je stosować nadmiernej swobody przy ustalaniu w praktyce zakresu podmiotowego i przedmiotowego ograniczeń konstytucyjnych wolności i praw jednostki. Założenie to można określić jako zasadę określoności ustawowej ingerencji w sferę konstytucyjnych wolności i praw jednostki." ${ }^{35}$ Niejasne i nieprecyzyjne formułowanie przepisu powoduje niepewność jego adresatów co do ich praw i obowiązków. Stwarza nazbyt szerokie ramy dla organów stosujących ten przepis, które w istocie muszą zastępować prawodawcę w zakresie tych zagadnień, a które uregulował w sposób niejasny, nieprecyzyjny. Założenie to można określić ogólnie jako zasadę określoności ustawowej ingerencji w sferę konstytucyjnych wolności i praw jednostki. ${ }^{36}$

Druga grupa definicji jest oparta na kryteriach językowych i według Trybunału Konstytucyjnego istotne są: poprawność, jasność, precyzja, kompletność, jednoznaczność i komunikatywność. ${ }^{37}$ Wspominając o tej grupie definicji można przytoczyć wyrok z dnia 21 lutego 2006 r. (K 1/05), w którym Trybunał Konstytucyjny stwierdza, że zasada poprawnej legislacji nakazuje formułowanie przepisów w sposób precyzyjny, jasny i poprawny pod względem językowym, a także uznał za konieczne „stanowienie przepisów prawa w sposób logiczny i konsekwentny, z poszanowaniem zasad ogólnosystemowych oraz zachowaniem należytych aksjologicznych standardów."

Wymóg jasności dla Trybunału oznacza „obowiązek tworzenia przepisów klarownych i zrozumiałych dla ich adresatów, którzy od racjonalnego ustawodawcy oczekiwać mogą stanowienia norm niebudzących wątpliwości co do treści nakładanych obowiązków i przyznawanych praw" ${ }^{38}$ Trybunał Konstytucyjny odnosi się również do kryterium zrozumiałości przepisu na gruncie języka powszechnego. ${ }^{39}$ Oparciem dla tego kryterium, jak i dla całej zasady określoności, jest m.in. prze-

\footnotetext{
33 Ibidem, s. 76.

34 Ibidem, s. 77.

35 Wyrok TK z 30 marca 2004 r., K. 32/03.

36 Wyrok TK z 30 października 2001 r., K 33/00.

37 I. Dziewulska-Gaj, O nieokreśloności konstytucyjnej zasady określoności, s. 77 i powołane tam orzeczenia TK.

38 M.in. wyrok TK z 21 marca 2001 r., K. 24/00, z 29 października 2003 r., K 53/02, z 28 lutego 2006 r., P 13/2005, z 17 maja 2006 r., K 33/05, z 27 listopada 2006 r., K 47/04, z 5 grudnia 2007, K 36/06.

39 Wyrok TK z 19 maja 2011 r., K 20/09.
} 
pis $§ 6$ Zasad Techniki Prawodawczejej ${ }^{40}$ stanowiący, że przepisy ustawy redaguje się tak, aby dokładnie i w sposób zrozumiały dla adresatów zawartych w nich norm wyrażały intencje prawodawcy. Precyzja przepisu winna się przejawiać w konkretności obowiązków i praw, aby ich treść była oczywista i pozwalała na ich egzekwowanie. Precyzja jest związana z jasnością ${ }^{41}$ Trybunał Konstytucyjny określa precyzję „odpowiednią szczegółowością unormowania." ${ }^{42}$

Kryterium kompletności według Trybunału Konstytucyjnego „to określenie wszystkich podstawowych elementów ograniczenia danego prawa i wolności, tak, aby już na podstawie lektury przepisów ustawy można było wyznaczyć kompletny zarys (kontur) tego ograniczenia." ${ }^{{ }^{43}}$ Przy tym należy mieć na uwadze treść $\S 146$ ust. 2 ZTP, z którego wynika, że jeżeli norma ma znajdować zastosowanie tylko w określonych okolicznościach, okoliczności te jednoznacznie i wyczerpująco wskazuje się w przepisie prawnym przez rodzajowe ich określenie.

Podsumowując, Trybunał Konstytucyjny stwierdził, że efektem stosowania zasady określoności muszą być przepisy precyzyjne, jasne, adekwatne do zamiaru prawodawcy, prowadzące do komunikatywności. ${ }^{44}$

Biorąc pod uwagę powyższą charakterystykę zasady określoności uważam (zd. K.Cz-K), że przepisy u.k.u.r., które były powyżej przedmiotem analizy, a które w założeniu ustawodawcy mają stać na straży ochrony gospodarstwa rodzinnego, nie spełniają wymogów tej zasady.

W literaturze sformułowano przesłanki prawidłowego korzystania ze zwrotów niedookreślonych, które z całą pewnością można odnieść również do przepisów chroniących własność rolniczą.

Pierwsza grupa przesłanek kierowana jest do ustawodawcy. I tak uważa się, że zwroty niedookreślone należy umieszczać w tekście tylko wówczas, gdy są one najkorzystniejszym środkiem do zapewnienia elastyczność prawa. Aby zagwarantować precyzyjność zwrotu niedookreślonego, należy jak najdokładniej doprecyzować nazwę kontekstową. W miarę możliwości należy zastępować zwrot nieostry określeniem, które precyzuje granice pasa nieostrości. Wówczas z jednej strony zapewniona jest precyzyjność zapisu, z drugiej jednak nadal pozostaje pewien przedział uwzględniania okoliczności. Kolejną istotną wskazówką jest to, aby unikać takich zwrotów niedookreślonych, które wymagają uwzględnienia kilku kryteriów jedno-

Rozporządzenie Prezesa rady Ministrów z 20 czerwca 2002 r., w sprawie „Zasad techniki prawodawczej” (Dz.U. z 2002 r. nr 100, poz. 908).

Wyrok TK z 21 marca 2001 r., K. 24/00, 29 października 2003 r., K 53/02, z 21 lutego 2006 r., K 1/05, z 28 lutego 2006 r., P 13/2005, 17 maja 2006 r., K 33/05, z 27 listopada 2006 r., K 47/04, z 5 grudnia 2007, K 36/06, z 7 kwietnia 2011 r., K 4/2009.

Wyrok TK z 30 października 2001 r., K 33/00, z 22 maja 2002, K 6/02, z 13 października 2008 r., K 16/07, z 18 marca 2010 r., K 8/08, z 7 kwietnia 2011 r., K 4/09.

Wyrok TK z 5 maja 2004 r., P 2/03.

Wyrok TK z 21 kwietnia 2009 r., K 50/07, z 24 lutego 2003 r., K 28/02, z 18 marca 2010 r., K 8/08. 
cześnie. Przy konieczności skorzystania z tego typu określeń złożonych, należy zachować szczególną staranność, w miarę możliwości wskazując na kryteria, które należy uwzględnić. ${ }^{45}$

Druga grupa przesłanek kierowana jest do organów stosujących prawo. Po pierwsze, ważne jest, aby organa stosujące prawo prawidłowo stosowały przepisy. Zwroty niedookreślone nabierają szczególnego znaczenia właśnie na etapie stosowania prawa. Stąd też to na podmiotach stosujących prawo ciąży odpowiedzialność za prawidłowe posługiwanie się pojęciami nieostrymi. Status podmiotu stosującego klauzule generalne i zwroty niedookreślone ma kluczowe znaczenie dla oceny konstytucyjności przepisu, który podmiot upoważnia do ingerencji w prawa obywatelskie. ${ }^{46}$ Jest to szczególnie istotne w przypadku statusu Prezesa ANR jako organu wydającego decyzję i samej ANR. Agencja jest państwową osobą prawną. Prezes jest organem Agencji; kieruje Agencją i reprezentuje ją na zewnątrz. Prezesa Agencji powołuje Prezes Rady Ministrów, na wniosek ministra właściwego do spraw rozwoju wsi. W konsekwencji powoływanie i odwoływanie stojącego na czele Agencji Prezesa jest związane ze zmianami gabinetów rządowych. Prezesowi mogą być wydawane polecenia służbowe przez ograna naczelne, które właściwie minimalizują samodzielność tej Agencji jako odrębnej państwowej osoby prawnej. Ponadto, budżet Agencji ustalany jest przez Radę Ministrów i Ministra Finansów przy udziale Ministra Rolnictwa i Rozwoju Wsi. Dlatego z punktu widzenia obecnych funkcji, zadań i pozycji ustrojowej Agencji określić ją można jako centralny organ administracji rządowej. ${ }^{47}$

Po drugie, podkreśla się konieczność zachowania odpowiednich gwarancji proceduralnych dotyczących wypełniania zwrotów niedookreślonych treścią, tj. aby podjęte przez organa decyzje były w ramach prawidłowo prowadzonego postępowania i by były prawidłowo uzasadniane. Oznacza to, że konieczne jest właściwe uzasadnienie treści podjętych na podstawie przepisów charakteryzujących się nieostrością, dokładne wyjaśnienie rozumienia danego zwrotu w konkretnej sprawie.

\section{Podsumowanie}

Omówione wyżej nowe uregulowania wprowadzono do u.k.u.r. „w celu wzmocnienia ochrony i rozwoju gospodarstw rodzinnych, które w myśl Konstytucji Rzeczypospolitej Polskiej stanowią podstawę ustroju rolnego Rzeczypospolitej Polskiej, dla zapewnienia właściwego zagospodarowania ziemi rolnej w Rzeczypo-

45 M. Śliwka, Znaczenie zwrotów niedookreślonych na tle orzecznictwa polskiego Trybunału Konstytucyjnego, s. 269 i powołana tam literatura.

Orzeczenie TK z 16 stycznia 2006 r., SK 30/05, OTK Zu nr 1/A/2006, poz. 2.

47 M. Możdżeń-Marcinkowski, [w:] Prawo rolne, Paweł Czechowski (red.), Warszawa 2011, s. 125-126, zob. również K. Czerwińska-Koral, Nowe funkcje Agencji Nieruchomości Rolnych w świetle ustawy z dnia 5 sierpnia 2015 r. o kształtowaniu ustroju rolnego, „Roczniki Administracji i Prawa” 2015, z. 1, s. 187 i n. 
spolitej Polskiej, w trosce o zapewnienie bezpieczeństwa żywnościowego obywateli i dla wspierania zrównoważonego rolnictwa prowadzonego w zgodzie z wymogami ochrony środowiska i sprzyjającego rozwojowi obszarów wiejskich (...).” Niemniej jednak uważam, że zawarte w przepisach zwroty niedookreślone oraz zbyt szeroki zakres swobodnego uznania organów administracji decydujących o własności rolnej (ANR, Prezesa ANR) wręcz osłabiają założoną ochronę gospodarstw rodzinnych. ${ }^{48}$ Brak pewności co do decyzji organu (w szerokim i wąskim rozumieniu), co do tego czy zostały wykazane wszystkie wymagane okoliczności, co do przesłanek, po których wystąpieniu organ wykona prawo pierwokupu czy złoży oświadczenie o nabyciu, wyda decyzję zawierająca zgodę na nabycie, może podważać poczucie bezpieczeństwa i perspektywy stanowiące podstawową wartość prawa własności ${ }^{49}$

Podkreślić należy, że możliwość używania przez prawodawcę wyrażeń nieostrych $\mathrm{w}$ przepisach stanowi wyjątek od zasady określoności prawa. ${ }^{50}$ Wystąpienie niejasności we wskazanych przepisach prawa pozostawia nadmierną swobodę organom stosującym prawo i tym samym powoduje brak pewności prawa. Zauważalne jest istnienie w przepisach luzu decyzyjnego, co jest związane ze świadomymi konstrukcjami prawodawczymi (sposób sformułowania przepisów, odesłania do kryteriów pozaprawnych). Za to odpowiada m.in. „kryzys” ustawodawstwa, przez co należy rozumieć ciągłe zmiany przepisów prawa i niejednokrotnie ich wątpliwą jakość. ${ }^{51}$

Jak pisał W. Pańko, współcześnie ochrona własności powinna koncentrować się na precyzyjnym określeniu generalnych zasad i granic jej ewentualnych ograniczeń. Dlatego też winno poszukiwać się takich rozwiązań proceduralnych, które w zakresie stosowania ograniczeń prawa własności będą niwelować arbitralność administracji m.in. przez współdziałanie administracji z różnymi formami specjalistycznych i społecznych organów. ${ }^{52}$ Tego typu współdziałanie może zaistnieć dla wykazania przesłanki „dawania należytego prowadzenia działalności rolniczej” (art. 2 a ust. 4 pkt 2 ppkt b). M. Korzycka zaproponowała w tym zakresie wprowadzenie do ustawy przepisu określającego warunki, jakie mają być brane pod uwagę, przy ocenie rękojmi należytego prowadzenia działalności rolniczej, tj. opinia izby rolniczej - samorządu zawodowego rolników, w którym członkostwo jest obowiązkowe i powstaje w mocy prawa $\mathrm{z}$ racji wykonywania zawodu rolnika, czy opi-

Braków tych nie niweluje sformułowanie ogólnych zasad analizy celowości nabycia w zarządzeniu nr 20/16 Prezesa Agencji Nieruchomości Rolnych z dnia 13 maja 2016 r. w sprawie realizacji przez oddziały terenowe ANR prawa pierwokupu i prawa nabycia określonych w ustawie z dnia 11 kwietnia 2003 r. o kształtowaniu ustroju rolnego, bowiem jest tylko dokument wewnętrzny Agencji.

49 W. Pańko, O prawie własności..., op. cit., s. 208-209.

50 A. Piaskowy, Klauzule generalne w projekcie nowego kodeksu cywilnego, Transformacje Prawa Prywatnego 2012, nr 3, s. 2.

51 E. Wagiel, Stosowanie czy tworzenie prawa - prawo sędziowskie, [w:] Sądowe stosowanie prawa, B. Dolnicki (red.), Katowice 2014, s. 12-13.

52 W. Pańko, O prawie własności..., op. cit., s. 199-213. 
nia sołtysa o prowadzeniu gospodarstwa rolnego. W przypadku nabycia przez osobę prawną należałoby dołączyć statut osoby prawnej, stwierdzający zakres kompetencji i kwalifikacji osób zatrudnionych przez osobę prawną w zakresie prowadzenia działalności rolniczej. ${ }^{53}$ Natomiast w przypadku art. 2a ust. 4 pkt 2 ppkt c dla wykazania przesłanki braku ,nadmiernej koncentracji gruntów rolnych” zaproponowano wprowadzenie do u.k.u.r. przepisu o następującej treści: „w celu oceny czy zaistniała «nadmierna koncentracja» oraz «względy społeczno-gospodarcze» minister właściwy do spraw rozwoju wsi powołuje zespół doradczy, złożony z niezależnych od władzy publicznej ekspertów." 54

W zakresie kontroli ograniczeń i ochrony własności należy odnieść się do niezawisłego sądownictwa. Tylko niezawisły sąd może stać na straży wolności i praw jednostki, jak też praw innych podmiotów. ${ }^{55}$ Należy zatem żałować, że w u.k.u.r. nie zawarto norm dających możliwość odwołania do sądów administracyjnych, które sprawdzałyby stosowanie prawa w sytuacjach zwrotów niedookreślonych. Bowiem nawet uznaniowy charakter decyzji nie wyklucza kontroli tych decyzji przez sądy administracyjne. Wówczas kontrola polega na sprawdzeniu, czy jej wydanie nastapiło w wyniku prawidłowo przeprowadzonego postępowania i w oparciu o dokładnie wyjaśniony stan faktyczny. Sąd administracyjny bada również, czy decyzja taka nie nosi cech dowolności, natomiast sam wybór rozstrzygnięcia, dokonywany na podstawie kryteriów słuszności i celowości, pozostaje już poza kontrolą sądowo-administracyjną (wyrok NSA z 23 września 1996, /SA/Ka 1418/95/). ${ }^{56}$

Na koniec podkreślić należy, że precyzyjnie określona ochrona gospodarstwa rodzinnego daje podstawy do stwierdzenia, że spełnione są wszystkie funkcje własności. ${ }^{57}$ Tylko takie przepisy zapewniają realną ochronę własności, dają gwarancję niezależności i poczucie bezpieczeństwa oraz stabilizacji i - wreszcie - poczucie pewności właściciela. Pewność jest jedną z głównych wartości prawa w ogóle. Wśród przesłanek warunkujących pewność wymienia się: 1) jasne i pełne określenie źródeł prawa, 2) jednoznaczność kwalifikacji sytuacji prawnych i brak sprzecz-

M. Korzycka, Analiza prawna przepisów ustawy o wstrzymaniu sprzedaży nieruchomości..., op. cit., s. 6; w zarządzeniu nr 20/16 Prezesa Agencji Nieruchomości Rolnych z dnia 13 maja 2016 r. w sprawie realizacji przez oddziały terenowe ANR prawa pierwokupu i prawa nabycia określonych w ustawie z dnia 11 kwietnia 2003 r. o kształtowaniu ustroju rolnego czytamy, że zasadność korzystania lub rezygnacji skorzystania z prawa pierwokupu/wykupu dokumentowana jest na podstawie m.in. opinii gmin, izb rolniczych, sołtysa lub dokumentów wewnętrznych sporządzonych przez pracownika oddziału koordynującego realizację u.k.u.r.

$54 \quad$ Ibidem, s. 7.

55 A. Matysiakiewicz, M. Męczyńska, Sądowoadministracyjny model stosowania prawa jako źródło problemów orzeczniczych organów administracji publicznej oraz ogólnego poczucia niesprawiedliwości, [w:] Sądowe stosowanie prawa, B. Dolnicki (red.), Katowice 2014, s. 29.

56 A. Ostrowska, Teoretyczne aspekty uznania administracyjnego, op. cit. s. 29.

57 Zob. W. Pańko, O prawie własności i jego współczesnych funkcjach, op. cit. s. 199-213, który wymieniał następujące funkcje własności: funkcja gwaranta wolności, funkcja bezpieczeństwa, majątkowa funkcja prawa własności, funkcja produkcyjna, funkcja socjalna oraz funkcja porządkująca oraz współcześnie zarysowana funkcja ekologiczna własności rolniczej, por. T. Kurowska, Ekologiczna funkcja własności rolniczej, Księga pamiątkowa poświęcona 40-leciu pracy naukowej A. Lichorowicza, „Studia luridica Agraria” 2001, t. II, T. Kurowska, Renesans własności rolniczej, „Przegląd Prawa Rolnego” 2014, nr 2. 
ności w tym zakresie, 3) pewność rzeczywistego respektowania uprawnień i legalności działania władzy, 4) przewidywalność skutków prawnych określonego stanu (zachowania). Dwie pierwsze przesłanki są związane z jakością prawa, a więc stwarzają wymóg istnienia jednoznacznych konstytucyjnych gwarancji dla prawa własności, precyzyjnego określenia materialnoprawnych i proceduralnych ram stanowienia ograniczeń prawa własności, spójności różnych sfer regulacji kształtującej treść prawa własności i jego wykonywanie. Spełnienia tych dwóch przesłanek moim zdaniem w nowych przepisach u.k.u.r. zabrakło. 
UNDERDETERMINED TERMS IN THE AGRICULTURAL SYSTEM STRUCTURING ACT

Keywords: Underdetermined terms, family farm protection, administrative discretion, principle

A number of changes to the Agricultural System Structuring Act were introduced by the provisions of the Suspension of Sale of Properties from the Agricultural Property Stock of the State Treasury Act of 11 April 2003. The changes were intended to improve the protection for family farms in Poland and increase their development. Unfortunately, the new regulations are imprecise. They contain many harsh and underdetermined expressions. They also give too much discretion to the administration authorities that take decisions on agricultural property. All that undermines the sense of security and the principle of legal certainty. Consequently, it weakens the protection for family farms that it intended to improve.

\section{Bibliografia:}

Bochania K., Znaczenie klauzul generalnych w stosowaniu prawa krajowego i międzynarodowego, [w:] Klauzule generalne w prawie krajowym i obcym, L. Zacharko (red.), Katowice 2016.

Bogucka I., Państwo prawne a problem uznania administracyjnego, „Państwo i Prawo” 1992, nr 10.

Czerwińska-Koral K., Nowe funkcje Agencji Nieruchomości Rolnych w świetle ustawy z dnia 5 sierpnia 2015 r. o kształtowaniu ustroju rolnego, „Roczniki Administracji i Prawa” 2015, z. 1.

Dziewulska-Gaj I., O nieokreśloności konstytucyjnej zasady określoności, [w:] Sądowe stosowanie prawa, B. Dolnicki (red.), Katowice 2014.

Gilbert-Studnicki T., Wieloznaczność leksykalna w interpretacji prawniczej, Kraków 1978.

Gregorczyk D., Stosowanie prawa administracyjnego przez sąd administracyjny, [w:] Sądowe stosowanie prawa, B. Dolnicki (red.), Katowice 2014.

Korzycka M., Analiza prawna przepisów ustawy o wstrzymaniu sprzedaży nieruchomości Zasobu Własności Rolnej Skarbu Państwa oraz o zmianie niektórych ustaw zwana dalej ustawą (druk senacki nr 124), www. senat.gov.pl/prace/opinie-i-eksperzyzy.

Kurowska T., Ekologiczna funkcja własności rolniczej, Księga pamiątkowa poświęcona 40-leciu pracy naukowej A. Lichorowicza, „Studia Iuridica Agraria” 2001, t. II.

Kurowska T., Renesans własności rolniczej, „Przegląd Prawa Rolnego” 2014, nr 2.

Maj K., Zmiany w ustawie o kształtowaniu ustroju rolnego obowiązujące od dnia 30 kwietnia 2016 r., „Krakowski Przegląd Notarialny” 2016, nr 2.

Matysiakiewicz A., M. Męczyńska, Sądowoadministracyny model stosowania prawa jako źródło problemów orzeczniczych organów administracji publicznej ora ogólnego poczucia niesprawiedliwości, [w:] Sądowe stosowanie prawa, B. Dolnicki (red.), Katowice 2014.

Marmor A., Varietes of Vadueness In the Law, „USC Legal Studiem Research Paper Series” 2013, nr 12-8. 
Morawski L., Wstęp do prawoznawstwa, Torun 1996.

Możdżeń-Marcinkowski M., [w:] Prawo rolne, Paweł Czechowski (red.), Warszawa 2011.

Ostrowska A., Teoretyczne aspekty uznania administracyjnego, [w:] Wykładnia prawa. Odrębności w wybranych gałęziach prawa, Lublin 2006.

Pańko W., O prawie własności i jego współczesnych funkcjach.

Piaskowy A., Klauzule generalne w projekcie nowego kodeksu cywilnego, „Transformacje prawa prywatnego" 2012, nr 3.

Piekarczyk S., Wielokierunkowa nieostrość w sądowym stosowaniu prawa Intencja prawodawcy a dyskrecjonalność sędziowska - antynomia czy kongruencja?, [w:] Klauzule generalne w prawie krajowym i obcym, L. Zacharko (red.), Katowice 2016.

Pietrzykowski T., Ujarzmienie Lewiatana - szkice o idei rządów prawa, Katowice 2014.

Pisuliński J., O niektórych osobliwościach obrotu nieruchomościami rolnymi, „Rejent” 2016, nr 5.

Śliwka M., Znaczenie zwrotów niedookreślonych na tle orzecznictwa polskiego Trybunału Konstytucyjnego, „Studia Iuridica Lublinesia” 2010, nr 1.

Truszkiewicz Z., Nieruchomość rolna i gospodarstwo rolne w rozumieniu U.K.U.R., „Krakowski Przegląd Notarialny" 2016, nr 2.

Wagiel E., Stosowanie czy tworzenie prawa - prawo sędziowskie, [w:] Sądowe stosowanie prawa, B. Dolnicki (red.), Katowice 2014. 